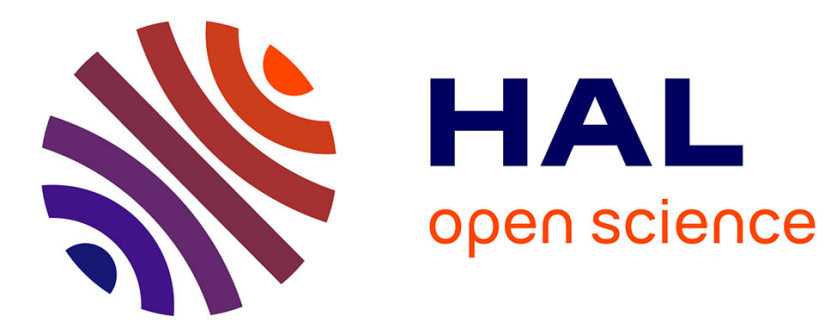

\title{
PRESSURE EFFECTS ON ELECTRICAL CONDUCTIVITIES IN INTERCALATED GRAPHITE AND DOPED POLYPYRROLE
}

\author{
B. Lundberg, B. Sundqvist, W. Salaneck
}

\section{- To cite this version:}

B. Lundberg, B. Sundqvist, W. Salaneck. PRESSURE EFFECTS ON ELECTRICAL CONDUCTIVITIES IN INTERCALATED GRAPHITE AND DOPED POLYPYRROLE. Journal de Physique Colloques, 1984, 45 (C8), pp.C8-213-C8-216. 10.1051/jphyscol:1984840 • jpa-00224341

HAL Id: jpa-00224341

https://hal.science/jpa-00224341

Submitted on 1 Jan 1984

HAL is a multi-disciplinary open access archive for the deposit and dissemination of scientific research documents, whether they are published or not. The documents may come from teaching and research institutions in France or abroad, or from public or private research centers.
L'archive ouverte pluridisciplinaire HAL, est destinée au dépôt et à la diffusion de documents scientifiques de niveau recherche, publiés ou non, émanant des établissements d'enseignement et de recherche français ou étrangers, des laboratoires publics ou privés. 


\author{
B. Lundberg, B. Sundquist and W.R. Salaneck* \\ Department of Physics, University of Umed, S-901 87 Umed, Sweden \\ *Institute of Physies and Measurement Technology, University of \\ Linkoping, S-581 83 Linkoping, Sweden
}

Résumé - Nous avons mesurë la résistivité électrique, jusqu ${ }^{1}$ à $2.5 \mathrm{GPa}$ et à Ta température ambiante, des graphites intercalés $\mathrm{C}_{n} \mathrm{FeCl}_{3}, \mathrm{C}_{n} \mathrm{SbF}_{5}$ et $\mathrm{C}_{n} \mathrm{HNO}_{3}$. L'augmentation de la résistance jusqu'à $2.5 \mathrm{GPa}$ est sensiblement la même dans les trois cas. On a constaté une transition de phase dans chacun des deux derniers matëriaux, les caractéristiques de ces transitions étant différentes. Nos résultats sur la variation de la résistance du polypyrrole sont en accord avec la théorie de "sauts à pas variable". I l parâtt que la densité d'états au niveau Fermi augmente avec la pression.

\begin{abstract}
We have measured the pressure dependence up to $2.5 \mathrm{GPa}$ of the electrical resistance of the acceptor intercalated graphites $\mathrm{C}_{n} \mathrm{FeCl}_{3}$, $\mathrm{C}_{n} \mathrm{SbF}_{5}$, and $\mathrm{C}_{n} \mathrm{HNO}_{3}$. The slope of resistance versus pressure is approximately the same in all cases. Two different types of high pressure transitions are observed in $\mathrm{C}_{n} \mathrm{SbF}_{5}$ and $\mathrm{C}_{n} \mathrm{HNO}_{3}$. The results of electrical resistance measurements under pressure in polypyrrole are consistent with a simple extension of the variable-range-hopping model. We infer for this material that the density of states at the Fermi level increases with pressure.
\end{abstract}

\title{
INTRODUCTION
}

During the past year we have begun a study of the pressure dependence of resistance in graphite intercalated compounds (GIC's) and doped polypyrrole (PPy). A common behaviour of these organic materials is their large conductivity after doping with similar agents. Typical values are $10^{5} \mathrm{~S} / \mathrm{cm}$ for GIC's (in plane), and $10^{2} \mathrm{~S} / \mathrm{cm}$ for doped PPy, as compared to that of copper, $5.8 \cdot 10^{5} \mathrm{~S} / \mathrm{cm}$. Also, very few high pressure measurements have been performed on these materials and existing results are contradictory. As will be shown below our results on $\mathrm{HNO}_{3}$-GIC are entirely incompatible with those of Iye et a $/ 1 /$. Regarding polymers the pressure dependence of the optical absorption $/ 2 /$ and the electrical conductivity $/ 3 /$ in polyacetylene, (CH) $x$, have been reported previously. In this first study of the pressure dependence of $x$, the electrical conductivity in boron-fluoride doped PPy we will examine the MottDavis /4/ variable range hopping (VRH) model, which has been used previously to fit the $\sigma(T)$ data for polypyrrole $/ 5,6 /$.

\section{EXPERIMENTAL}

The high pressure experiments have been performed in a conventional piston-cylinder apparatus $17 /$. As pressure transmitting medium in a standard Teflon ${ }^{\circledR}$ cell we have used a 50/50 mixture of normal- and isopentane, providing hydrostatic conditions to about $7 \mathrm{GPa}$ at room temperature. The temperature is $1 \mathrm{jmited}$ to the range between $250 \mathrm{~K}$ to $300 \mathrm{~K}$ due to the massive nature of the apparatus.

Stage $2 \mathrm{FeCl}_{3}$ and stage $1 \mathrm{SbF}_{5}$ samples were obtained from Professor $\mathrm{F}$. Lincoln Vogel, and stage $2 \mathrm{HNO}_{3}$ samples from Professor John E. Fischer, both of the Uni- 
versity of Pennsylvania, Philadelphia, U.S.A. The conductivities of these samples, at room temperature and ambient pressure, were measured by a contactless open coil induction method $/ 8 /$. Under pressure we used a contactless, closed toroidal core method $/ 9 \%$.

Boron-fluoride doped PPy samples were prepared in Linköping according to standard procedures $/ 5 /$ and sent under inert atmosphere to Umea for high pressure study using the 4-point contact method. Before pressurizing $R(T)$ was measured between $77 \mathrm{~K}$ and $300 \mathrm{~K}$.

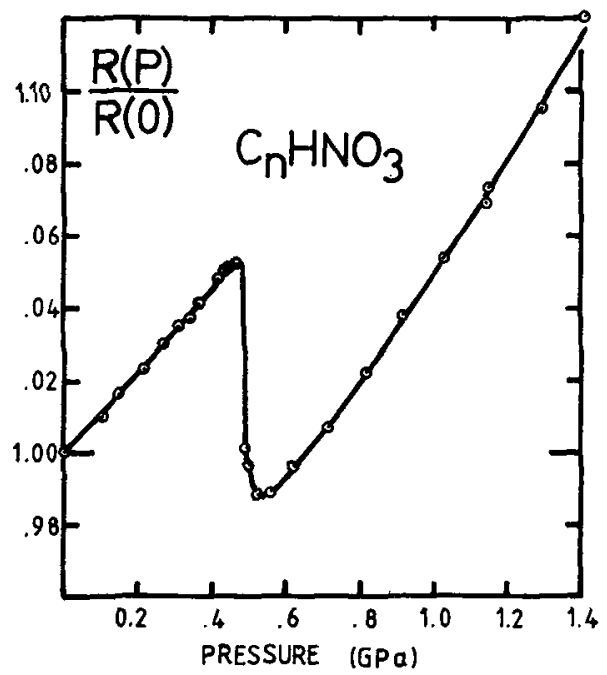

Fig. 1 - Relative resistance of $\mathrm{Cn}_{n} \mathrm{HNO}_{3}$ versus pressure.

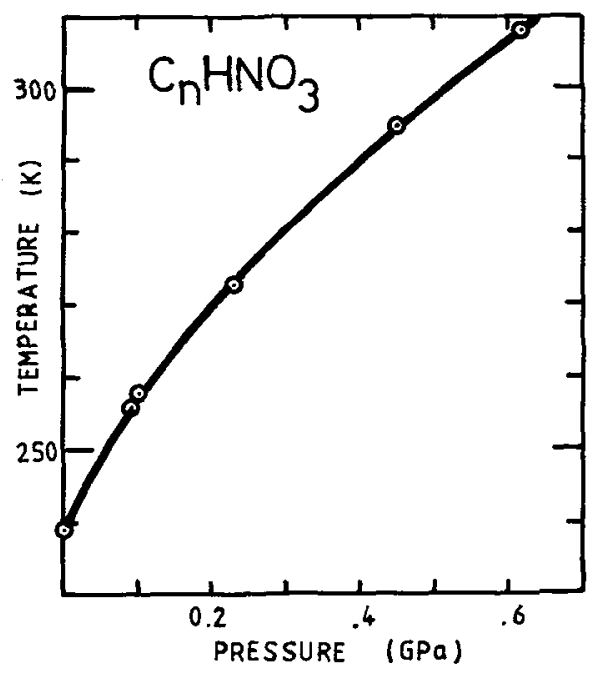

Fig. 2 - Phase diagram of $\mathrm{C}_{n} \mathrm{HNO}_{3}$.

\section{RESULTS AND DISCUSSION}

In all the acceptor intercalated samples, i.e. $\mathrm{FeCl}_{3}{ }^{-}, \mathrm{SbF}_{5}{ }^{-}$, and $\mathrm{HNO}_{3}-\mathrm{GIC}^{\prime} \mathrm{s}$, examined here, the pressure coefficients of resistance, $(1 / R(0))\left(d R(P)^{3} / d P\right)$, have about the same value, $+0.1 \mathrm{GPa}^{-1}$, which contradicts that of Iye et a $11 \%$, who report $-1.0 \mathrm{GPa}^{-1}$. This discrepancy was noted in earlier measurements by the authors $/ 10 /$ on the $\mathrm{FeCl}_{3}$ - and $\mathrm{SbF}_{5}-\mathrm{GIC}^{\prime} \mathrm{S}$, and now on $\mathrm{HNO}_{3}-\mathrm{GIC}$ for conclusive comparison.

In the $\mathrm{SbF}_{5}$-GIC we have reported in Ref. $110 /$ a very slow (24 hours) phase (stage) transition at about $1.2 \mathrm{GPa}$, accompanied by a further increase in resistance. In the $\mathrm{HNO}_{3}$-variety we observe an almost instantaneous order-disorder transition, accompanied by a sharp drop in resistance, as can be seen in Fig. 1. At room temperature the transition occurs at about $0.45 \mathrm{GPa}$. The hysteres is is about $0.05 \mathrm{GPa}$ on decreasing the pressure. The corresponding hysteres is in $\mathrm{C}_{n} \mathrm{SbF}_{5}$ is about $0.5 \mathrm{GPa}$. At 1 bar the transition temperature is about $240 \mathrm{~K}$, which is in agreement with reported data $/ 11 /$, and also verified at our laboratory by differential scanning calorimetry. The phase diagram, showing the boundary between the low temperature ordered structure and the high temperature disordered one, is shown in 
Fig. 2. The slope, $d T / d P$, of the phase boundary at room temperature and $0.45 \mathrm{GPa}$ is $91 \mathrm{~K} / \mathrm{GPa}$, and at atmospheric pressure and $240 \mathrm{~K}, 132 \mathrm{~K} / \mathrm{GPa}$. According to the theory of Divincenzo et al $/ 12 /$, based on the Clausius-Clapeyron equation, the change in slope of the phase boundary indicates a ratio $\Delta \Omega(0.45) / \Delta \Omega(0)=0.70$, where $\Delta \Omega$ equals the change in volume upon intercalation.

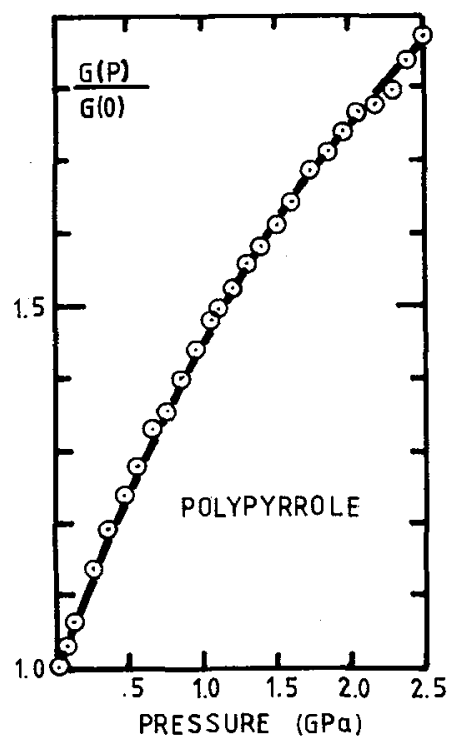

Fig. 3 - Relative conductance of polypyrrole versus pressure.

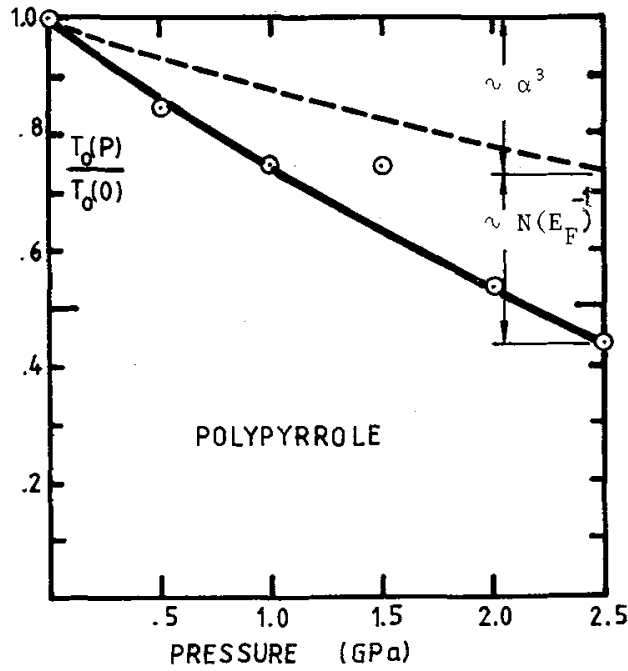

Fig. 4 - The VRH parameter $T_{0} \sim \frac{\alpha^{3}}{N\left(E_{F}\right)}$
versus pressure.

At room temperature and atmospheric pressure the polypyrrole samples had a dc conductivity in the range $35 \leqslant \sigma \leqslant 55 \mathrm{~s} / \mathrm{cm}$. A typical normalised curve of conductance, $G=1 / R$, versus pressure is shöwn in Fig. 3 and indicates an increase in sample conductance by $85 \%$ to $2.5 \mathrm{GPa}$.

In a previous paper $/ 13 /$ we have shown that the $T$-dependence at $P=1$ bar fits the VRH model $/ 4 /$,

$$
\sigma=A\left(T_{0} / T\right)^{\frac{1}{2}} \exp \left\{-\left(T_{0} / T\right)^{1 / 4}\right\} .
$$

It was also shown that the data fit equally well a function of the type $\sigma(T)=$ $\sigma_{0} T^{n}$. However, instead of being a constant, as in polyacetylene $(n \approx 13) / 14 /, n$ for PPy changes from 0.75 (at 1 bar) to 0.35 (at $2.0 \mathrm{GPa}$ ), and seems to be constant at $\mathrm{P}>2.0 \mathrm{GPa}$. This behaviour led us to consider the P-dependence in the VRH model. As a first approximation we assumed that the characteristic decay length of the localized state $1 / \alpha$ increases with pressure. Then, $\alpha=\alpha_{0}(1-h . P)$, where $h=0.04$ $\mathrm{GPa}^{-1}$ is the 1 inear compressibility, here taken equal to that of $(\mathrm{CH}) \mathrm{H} / \mathrm{s}$, since the compressibility of PPy is unknown. $T_{0}(P)$ in the $V R H$ equation now becomes $T_{0}(P)=T_{0}(0)(1-h \cdot P)^{3}$, where $T_{0}(0)=24 a^{3} / \pi k_{B} N\left(E_{F}\right)$, and $N\left(E_{F}\right)$ is assumed constant. In our samples, $\mathrm{T}_{0}(0)=1.0 \cdot 10^{5} \mathrm{~K}$, in agreement with previously published results $15 \%$. At low pressure this model agrees roughly with experiment, but at higher pressures it deviates significantly. At each pressure, $\mathrm{T}_{0}$ can be calculated from the slope of $\ln \left(\sigma T^{\frac{1}{2}}\right)$ versus $T^{-1} /{ }^{4}$. Fig. 4 shows the variation of $T_{0}$ with pressure obtained in this way. Supposing the value of $h$ used is reasonable, a best fit is 
obtained for $T_{0}(P) \sim(1-h \cdot P)^{8}$. Since $\alpha^{3} \sim(1-h \cdot P)^{3}$ it is reasonable to assume that the density of states, $N\left(E_{F}\right)$, increases considerably with increasing pressure.

We would like to thank Dr. Russel1 Ross and Professor Gunnar Bäckström for reading the manuscript. This work was financially supported by the Swedish Natural Science Research Councit.

\section{REFERENCES}

1. IYE Y., TAKAHASHI 0., TANUMA S,, TSUJI K. and MINOMURA S., J. Phys. Soc. Jäpan 51 (1982) 475.

2. MOSES D., FELDBLUM A., DENENSTEIN A.D., CHUNG T-C., HEEgER A.J. and MACDIARMID A.G., Mol. Cryst. Liq. Cryst. 83 (1982) 87.

3. FERRARIS J.P., WEBB A.W., WEBER D.C., FOX W.B., CARPENTER Jr. E.R. and BRANT P., Sol. State Commun. 35 (1980) 15.

4. MOTT, N.F. and DAVIS E.A., Electronic Processes in Non-Crystalline Materials (Clarendon Press, Oxford, 1979) Chapter ?.

5. KANAZAWA K.K., DIAZ A.F., GILL W.D., GRANT P.M., STREET G.B., GARDINI G.P. and KWAK J.F., Jour. Syn. Met. $1(1979 / 80) 329$.

6. WATANABE A., TANAKA M. and TANAKA J., Bul1. Chem. Soc. Japan 54 (1981) 2278.

7. SUNDQVIST B. and BACKSTROM G., High Temp. -High Pressures 9 (1977) 41.

8. SUNDQVIST B. and LUNDBERG B., J. Phys. E: Sci. Instrum, 16 (1983) 408.

9. SUNDQVIST B. and LUNDBERG B., in High Pressure in Science and Technology, C.G. Homan, R.K. MacCrone, and E. WhatTey (Editors) (ETsevier, New York 1984).

10. SUNDQVIST B. and LUNDBERG B., J. Phys. C: Solid State Phys. 17 (1984) L133.

11. WU T.C., VOGEL F.L., PENDRYS L.A. and ZELLER C., Material Science and Engineering 47 (1981) 161.

12. DIVINCENZO D.P., FUERST C.D. and FISCHER J.E., Phys. Rev. B 29, No 2 (1984) 1115.

13. LUNDBERG B., SUNDQVIST B., INGANAS 0., LUNDSTROMM I. and SALANECK W.R. To be published in Mol. Cryst. Liq. Cryst.

14. MOSES D., CHEN J., DENENSTEIN A., KAVEH M., CHUNG T.C., HEEGER A.J., MACDIARMID A.G. and PARK Y.W., Solid State Commun. 40 (1981) 1007. 